\title{
Pursuing epistemological plurality in South Africa's Eco-Schools: Discursive rules for knowledge legitimation
}

\author{
Lisa Ryan and Jo-Anne Ferreira, Southern Cross University, Australia
}

\begin{abstract}
Efforts to re-appropriate indigenous knowledges reveal a discursive friction experienced by Eco-School support workers in South Africa as they attempt to build an epistemologically pluralistic curriculum. This paper outlines the strategies that South African Eco-School support workers and teachers employ in negotiating this friction and highlights the discursive rules that govern what constitutes legitimate knowledge in the South African Eco-School. The unintended consequences of these strategies that may affect the representation of indigenous peoples is also discussed.
\end{abstract}

Key words: Eco-School, discourse analysis, indigenous knowledge, postcolonial theory.

\section{Introduction}

The Foundation for Environmental Education's Green Flag Eco-School Programme, originally designed in Europe, is the largest and most well-recognised environmental education programme in the world. Acknowledged by the United Nations Environment Programme (UNEP) as a model initiative for Education for Sustainability, it has been adopted in over 67 countries (Eco-Schools, 2014). Because of its wide reach into a variety of different cultural contexts, it is important to consider the ways in which a global programme such as Eco-Schools - underpinned as it is by a variety of western discourses - may work to standardise or 'colonise' environmental education internationally. However, such effects have not been well researched.

Drawing on a case study of the implementation of Eco-Schools in South Africa by the host organisation - the Wildlife and Environment Society of South Africa (WESSA) - we examine the ways in which the Eco-School programme legitimates and defines what counts as environmental education knowledge in South African Eco-Schools. Through an examination of the ways that Eco-School teachers negotiate different knowledges and knowledge systems in the course of their work, we explore how conflicting global and local discourses are contested, negotiated and worked through in the South African Eco-School. This is achieved through an analysis of 22 different Eco-School curriculum resources from the Foundation for Environmental Education (FEE) and WESSA, as well as interviews with 20 South African Eco-School support workers and teachers. We argue that there is a hybridisation of Eco-schooling knowledge and practices in South Africa, particularly in relation to the ways that scientific and indigenous knowledges are negotiated, and that this has implications for the way indigenous peoples and their knowledges are represented within and through the programme. 


\section{Background: Eco-Schools in South Africa}

The FEE Green Flag Eco-Schools Programme was originally launched by the Foundation for Environmental Education in Europe in 1994, as a direct response to the Sustainable Development Agenda championed at the Rio Earth Summit. The programme has expanded globally and is now the largest and fastest growing school-based environmental education programme internationally. As of 2017, over 51000 schools across 67 countries and over 19 million learners participated in Eco-Schools (Eco-Schools, n.d.).

A focus on the participation of students in actively managing the environmental and sustainability impacts of the school and in working towards positive environmental change is central to the Eco-Schools programme. This commitment to environmental management is evident in the Eco-Schools methodology, encompassing seven steps that schools should adopt:

Step 1: Establishment of the Eco-Schools Committee with broad participation across school stakeholders to guide the programme.

Step 2: Environmental Review to provide baseline data on environmental and sustainability impacts.

Step 3: Action Plan developed in collaboration with learners and teachers to target key parameters.

Step 4: Monitoring and Evaluation of targeted parameters.

Step 5: Linking the programme to the school curriculum.

Step 6: Informing and Involving the wider community.

Step 7: Development of an Eco-Code to ensure sustainability ethics are embedded in school culture. (Eco-Schools, 2014)

Eco-Schools able to demonstrate sufficient progress across a number of sustainability parameters such as water and energy use, waste, biodiversity, habitat, health and transport are awarded an International Green Flag. The Green Flag has become internationally recognised as an indication of environmental excellence and is thus a desirable status symbol (UNEP-FEE, 2003).

In 2003, under the auspices of WESSA, South Africa became the first country outside of Europe to adopt Eco-Schools, making the South African programme the longest running example of the programme outside Europe. The Green Flag award is a highly prized commodity in South African schools. Unlike many European countries who judge their Green Flag award on schools meeting a particular minimum standard, in South Africa the award is judged on each school submitting a portfolio that demonstrates the school's progression towards whole-school 
sustainability projects. A key difference then between the global Eco-Schools programme and South Africa's version is that schools are rewarded, not for meeting a particular standard, but for their progress towards particular sustainability goals.

As the national operator, WESSA is responsible for implementing the programme in South Africa within FEE's guidelines (FEE, 2012). Under these guidelines, WESSA pays an annual membership levy and must ensure that that the quality, integrity and international standing of the programme are maintained.

To assist schools in progressing towards sustainability, WESSA provides South African Eco-Schools with guidelines, a handbook, and a range of curriculum resources that explicitly link Eco-Schools themes to the South African national curriculum. In-school support for Eco-School projects is also provided through a network of node coordinators (Eco-School support workers) in each province. The role of WESSA Eco-School support workers is significant. They act as 'experts' and knowledge brokers of environmental education, interpreting and adapting the global programme to suit the South African context. Together with the curricular guidelines, Eco-School support workers - as 'experts' - exercise considerable power in the shaping and framing of what counts as legitimate Eco-schooling knowledges and practices in South Africa.

\section{Global and local Eco-schooling discourses: Negotiating discursive contestation}

Eco-schooling can be thought of as a 'discursive field' (Weedon, 1987:35) in that it contains a number of different and sometimes competing global and local discourses, with varying degrees of power that have shaped the systems of meaning and what counts as legitimate, 'true' knowledge within the Eco-School.

We know that many global discourses are privileged as 'universal' truths. These 'regimes of truth' (Foucault, 1980) are also at work defining what counts as valid knowledge in the Eco-School and thus have considerable effects in shaping Eco-schooling policies, practices and procedures everywhere FEE Eco-Schools operate. For example, in the Eco-School, the global sustainability discourse of ecological modernisation (Huckle, 2009; Ryan, 2017) is privileged. Ecological modernisation (Dryzek, 2013; Mol \& Sonnenfeld, 2000; Redclift, 1994) refers to a greening of contemporary neoliberal capitalism. It is generally conceived of as a reformist rather than radical discourse where environmental problems are considered as 'accidents on the way to progress', to be solved by whatever technical means are at our disposal (Colombo \& Porcu, 2014) As such, ecological modernisation priveleges scientific knowledge systems.

This scientific focus is clearly evident in Eco-Schools' concern for the monitoring and management of environmental problems, which are fundamental processes underpinning the programme. Strategies employed by Eco-Schools such as monitoring of resource and waste flows through environmental management systems and the adoption of technological 'fixes' to environmental problems are examples of mechanisms favoured by ecological modernisation (Howes, McKenzie, Gleeson, Gray, Byrne \& Daniels, 2010; Mol \& Sonnenfeld, 2000). South African Eco-Schools are clearly influenced by this powerful global Eco-School - and environmental - discourse. There are many examples of South African Eco-Schools 
undertaking ecologically modernist projects such as monitoring and reducing energy and water use through energy efficiency technologies such as geezer blankets and wastewater recycling systems (Ryan, 2017).

While analysis of the Eco-Schools programme shows that it is subject to global discourses such as the scientific discourse of ecological modernisation, at the same time, it is also strongly underpinned by local justice discourses that promote the inclusion and re-appropriation of indigenous knowledges. Re-appropriation refers to the uncovering and recovery of previously lost and subjugated knowledges for meaning-making in contemporary societies (Masuku van Damme \& Neluvhalani, 2004) (as opposed to appropriation (Giddens, 1991), which refers to the politics of knowledge creation, encompassing processes of oversight, transformation, marginalisation and subjugation). Yet within Eco-Schools, the re-appropriation of indigenous knowledge, itself a contested process (Kanu, 2011), does not always sit comfortably with the broader global ecological modernisation discourse that is highly technical and prioritises scientific knowledge.

Re-appropriating indigenous knowledges then presents a significant site of discursive contestation since it requires teachers to hold a number of divergent epistemological positions, including global scientific and local indigenous knowledges. These require Eco-School teachers to experience the limits of each discourse and actively negotiate their boundaries. In doing so, they encounter areas of compatibility, friction and impasse. How teachers manage this provides a particularly telling example of the ways in which global and local discourses are worked through and in which particular rules are laid down to validate particular versions of Eco-schooling knowledge.

When discourses are negotiated and the rules and 'knowledge hierarchies' (Dei, Hall \& Rosenberg, 2000) for each discourse are made clearer, the kinds of indigenous knowledges that can be used, in what contexts and by whom, also become clearer. Such rules can be interpolated from an examination of indigenous knowledge curriculum resources and from discussions with Eco-School workers and teachers about how they negotiate the relationships between indigenous and scientific knowledges in Eco-Schools.

\section{Research methods}

Data for this research were gathered from 16 semi-structured interviews and two focus groups, encompassing five Eco-School teachers and 15 Eco-School support workers. Participants were selected through snow-ball sampling (Valentine, 1997), where we were introduced to Eco-School teachers and support workers across six of South Africa's nine provinces (Eastern Cape, Gauteng, KwaZulu-Natal, Limpopo, North West and Western Cape) by Eco-School national and provincial coordinators as well as by participating teachers. Collectively, participants were drawn from a range of South Africa's schooling types including relatively well-funded urban and rural schools, low-income rural farm schools and low-income urban township schools. They also encompassed a variety of ethnic backgrounds. Table 1 provides basic demographic data on participants. In order to protect identities, demographic data were not broken down further into provincial or ethnic categories. 
Table 1. Key demographic categories of research participants

\begin{tabular}{|l|l|}
\hline EST 1 & Eco-School principal (former Model C rural school), White, male \\
\hline EST 2 & Eco-School teacher (low-income school, rural area), Black, male \\
\hline EST 3 & Eco-School teacher (low-income school, urban informal settlement), Black, female \\
\hline EST 4 & Eco-School teacher (low-income school, rural area), Black, male \\
\hline EST 5 & Eco-School teacher (low-income school, rural area), White, female \\
\hline ESW 1 & Eco-School support worker (node coordinator, rural area), Black, male \\
\hline ESW 2 & Eco-School support worker (node coordinator, urban township), White, female \\
\hline ESW 3 & Eco-School support worker (provincial coordinator), White, female \\
\hline ESW 4 & Eco-School support worker (node coordinator, urban/rural area), White, female \\
\hline ESW 5 & Eco-School support worker (provincial coordinator), Black, female \\
\hline ESW 6 & Eco-School support worker (node coordinator, rural area), Black, male \\
\hline ESW 7 & Eco-School support worker (provincial coordinator, urban/rural area), White, female \\
\hline ESW 8 & Eco-School support worker (node coordinator, urban/rural area), White, female \\
\hline ESW 9 & Eco-School support worker (provincial coordinator, urban/rural area), White, female \\
\hline ESW 10 & Eco-School support worker (node coordinator, urban/rural area), White, female \\
\hline ESW 11 & Eco-School support worker (provincial coordinator, urban/rural area), Black, female \\
\hline ESW 12 & Eco-School support worker (node coordinator, urban/rural area), White, female \\
\hline ESW 13 & Eco-School support worker (node coordinator, rural area), White, female \\
\hline ESW 14 & Eco-School support worker (provincial coordinator, urban/rural area), Black, female \\
\hline ESW 15 & Eco-School support worker (node coordinator, urban area), White, female \\
\hline
\end{tabular}

Semi-structured interview questions were designed with the aim of capturing the complexities of participants' experiences as South African Eco-School teachers and support workers. We hoped to encourage the sharing of stories in which participants' identities as Eco-School teachers and workers would be foregrounded. Our interview schedule was thus designed around a number of broad categories:

1. Research participants' autobiographical narratives as Eco-School teachers.

2. Professional opinions and thoughts about the global Eco-School programme.

3. Stories of challenge and tension in the Eco-School in South Africa.

A postcolonial lens was employed in analysis of the data to illuminate the everyday effects of power on teachers' perceptions of themselves and their work. Postcolonial concepts offer an innovative way of investigating teacher identity and self-perceptions of capacity and 
agency in environmental education because they emphasise the powerful colonising effects of discourse as well as the possibility of agency through discursive disruption. In particular, we focused on perceptions about the global and contextual forces that framed participants as Eco-School teachers and shaped their practice. We also wanted to elicit stories of resistance against such framing. Thus, our aim was to capture the 'third space' (Bhabha, 1994) or 'borderland culture' (Anzaldúa, 1987) that we hypothesised participants inhabit as South African Eco-School teachers.

\section{Mobilising indigenous knowledge in the South African Eco-School: Rules of discourse}

Since the 1980s, indigenous knowledges have gained increased attention in the field of environmental education (Ellen, 2002; Nygren, 1999; Shava, 2013). There has also been a range of United Nations and intergovernmental agreements advocating for the value of indigenous knowledges, such as the Declaration on the Rights of Indigenous Peoples (United Nations, 2007). These developments signal a major shift in power/knowledge relations between western scientific institutions and indigenous communities (Shava, 2013). As a result of a growing justice discourse, the value of indigenous communities and their knowledges is increasingly recognised. This is particularly so given that western science seems unable to answer many of the complex 'wicked' (Rittel \& Webber, 1973) problems of the contemporary world. Indigenous knowledges are now also seen as valuable sources of epistemological diversity (Lotz-Sisikta, 2002; Shava, 2013).

Many African writers have worked to define and articulate what is meant by indigenous knowledges in a Southern African context (e.g. Kumalo, 2017; Le Grange, 2012; Ramose, 2014; Odora Hoppers, 2002; Shava, 2013; Masuku van Damme \& Neluvhalani, 2004). Such writers present these not as isolated knowledges and beliefs, but rather as an integrated worldview consistent with a clear ethic for sustainable living. Le Grange (2012) for example points to the concepts of ubuntu (interdependence) and ukama (relationality) as key ethical paradigms underpinning African knowledge systems. Ubuntu is often defined as a concept that recognises the humanity in the 'Other' (with all their uniqueness and difference) - being a quality we owe to each other (Eze, 2010). This moral obligation, Le Grange (2012:143) argues, should not only be 'limited to human life, but extended to the natural environment'. Similarly, Ramose describes an African worldview as acting to 'promote life and avoid killing' (2014:68), elaborating that such a worldview extends an ethical position encompassing the living (including humans, plants and animals) and the 'living-dead or ancestors who continue to live with us, and leaving the land as good as we found it' (2014:75). These positions highlight the fundamental concern for the environment and sustainability in South African indigenous epistemes.

The increased willingness globally to engage with and re-appropriate indigenous knowledges is evident in South Africa, where it is clear that a re-affirmation of the value of indigenous knowledge is an important step in rebuilding pride and national identity (Lotz-Sisitka, 2006). The Indigenous Knowledges Systems Policy (2004), for example, demonstrates the commitment of the South African government to recognise, promote and develop indigenous 
knowledge systems (IKS) throughout a range of policy mechanisms including integration of IKS into the national curriculum. In the South African Eco-School, the value of indigenous knowledge has also been recognised through the inclusion of community and heritage as a core curriculum theme. However, despite governmental and organisational support, the mobilisation of IKS in both schools and Eco-Schools has been problematic. Our research adds to the contributions of others (Kumalo, 2017; Le Grange, 2012; Masuku van Damme \& Neluvhalani, 2004; Odora Hoppers, 2002; Ramose, 2014; Shava, 2008, 2013) in exploring the complex issue of re-appropriating IKS in the South African environmental education context.

Our research with Eco-School support staff and teachers, reveals an emerging tension of trying to build an epistemologically pluralistic curriculum where different knowledges can fit together into a workable framework. In their efforts to incorporate indigenous knowledge into the curriculum, Eco-School support workers are constantly negotiating the authenticity and epistemological commensurability of various knowledge systems. All the support workers interviewed mentioned the dilemmas faced when encountering ecologically destructive behaviours underpinned by traditional beliefs (such as the killing of frogs because they cause thunderstorms). A key challenge for them is how to raise the topic without causing offence. For example, in an interview with one of the Eco-School support workers, some of the challenges faced in negotiating these knowledge systems was raised:

I think it's very difficult and I think the way one does it is to be very careful because the last thing you want is for someone to get even more adamant that what they believe is correct. I think there is certain information that is completely incorrect, and that, one needs to just present, but I think it's the way that you do it. That's really important. It's not saying that you're absolutely wrong. (Eco-School Support Worker 7, 2012)

While denying the legitimacy of traditional beliefs behind environmentally destructive behaviours, some support workers were willing to concede there may be valuable lessons underlying the origin of such beliefs, which could perhaps be classified as knowledge. For example, one support worker said she tries to think about why certain beliefs arose:

Frogs shoot lightning from their eyes ... And then when you learn about what lightning is and how it's actually formed, it seems a little bit impossible that this could happen and maybe it is something that comes about because generally after a big thunderstorm first thing in spring, lots of frogs appear, and so there might be this link between thunderstorms and frogs, somehow, but it was something they'd gotten mixed up. Maybe we could challenge these ideas? (Eco-School Support Worker 3, 2012)

This support worker uses this example as a way of showing how the observations of previous generations, of frogs being seen in or after thunderstorms, could feasibly have led to the 'misconception' that frogs cause thunderstorms. She indicates that this example opens an opportunity to build on the observations made while also challenging the belief and in turn countering the negative environmental behaviours (such as killing frogs) that stem from the 
belief. Such an approach, while discounting the belief, does not discount the observation that more frogs are seen after thunderstorms.

Another support worker explains how such beliefs may have arisen from attempts to preserve and protect ecologically sensitive and important areas such as water sources:

I think there are beliefs that were in place to protect nature. To protect water from being polluted. To say to kids, there's a huge big snake waiting to eat you behind the lake. But let's think about why. Why your elders and your great, great, great, great, grandparents might have thought that it's important to have that myth? It's not just in Africa. There's Greek legends. There's Australian legends. There was a place for those things. (Eco-Schools Support Worker 3, 2012)

These approaches do not directly challenge the accuracy of the knowledge and importantly do not position scientific and indigenous knowledges as oppositional categories. Many Eco-School support workers went to great lengths to avoid directly opposing traditional beliefs in confrontational ways and adopted a range of different strategies to negotiate this area, leaving open the opportunity for epistemological plurality. For example, one support worker points to European examples of superstition as a way of demonstrating culturally parallel tendencies and an openness to self-critique:

... you bring some of your own colonial or European superstitions into the conversations and indicate how little substance they have. Like a black cat crossing your path or waking under a ladder ... and being able to laugh together about our shared idiosyncrasies and looking at examples of indigenous knowledge that are useful and practical and caring and bolstering those, so you're not brushing everything aside because of your viewpoints. (Eco-Schools Support Worker 3, 2012)

Another support worker's strategy is to appeal to reason, be it scientific or traditional. However, he also suggests alternative, sustainable behaviours that could be adopted instead:

We tried many ways to find a good way to approach people about these things. When we say 'Don't kill these things', it's not like we say, 'Don't do this, don't do it ... NEVER!'. No, we give them reasons why we say so. We say, 'Please don't cut down the whole tree, better you just cut some branches.' We say, 'Do it - but in a good way.' Like the old people, the San people, they used to hunt, but they only stayed in this place maybe for a month then they'd move to the other one so that the place can regrow. (Eco-Schools Support Worker 1, 2012)

Another support worker appeals to the logic of another dominant discourse within the community - religion. She deliberately frames problems or issues in religious terms, seeing religion as a more influential discursive logic than either scientific or indigenous knowledges:

I also try and play on the religious aspect of it and in all religions, environment actually is quite important ... the teachers in South Africa are actually very, very Christian. So I play on that. Are 
you saying God didn't know what he was doing when he made a snake or an owl?' Of course he did. There is a place for it. So it's my little cheat. (Eco-Schools Support Worker 9, 2012)

Other support workers found the issue of indigenous knowledge to be such a challenge that, if at all possible, they avoided having to address it. One support worker was quite self-reflective about the epistemological consequences and ethics of her negotiating strategies:

It's a tough one. As much as you don't want, it's a horrible thing to see owls being killed - Why do you deconstruct that? Why do you deconstruct that myth? What gives you the right to do that? How have I dealt with it? ... Myths are a tough one. I suppose just laying down the facts and for them to make the decisions, is all that I can do. And perhaps stating the order of things. If the owls go, what do you have instead? Is there anything alternative to the owls? But I tread very lightly there. If I don't have to get into the discussion, I won't. (Eco-Schools Support Worker 11, 2012)

In their efforts to implement an Eco-Schools programme in South Africa that hybridises indigenous knowledges with scientific knowledges, Eco-School support workers face a difficult task. Not all indigenous knowledges can be conceived of as environmentally friendly or benign and many unsustainable traditional practices are based on deeply rooted beliefs. Practices such as the widespread killing of owls, snakes and frogs (among other species) and the harvesting of animal parts for the muthi (traditional medicine) industry are all derived ostensibly from traditional indigenous knowledges.

Addressing unsustainable practices in indigenous knowledge systems is not simply a matter of correcting misinformation. Indigenous knowledges, including the examples cited above, are not just subjective ideas that have been dreamed up; they often have some basis in objective observation and empirical evidence. Vultures do possess acute vision and do have an uncanny ability to find prey; frogs do often come out in storms. Therefore, addressing epistemic unsustainability often requires extensive negotiation at the discursive level.

As outlined above, many of the Eco-School support workers interviewed demonstrated how they were engaged in this epistemological negotiation. None of them advocated strategies that directly confronted indigenous knowledges and behaviours, for fear of provoking negative reactions. They were far subtler in their tactics: some adopted discourses of alternative knowledge systems such as science or religion to provide alternative influential perspectives; some provoked a critical reflection on the knowledge by asking consequential questions; and some demonstrated parallel superstitions from European culture. A couple were also willing to acknowledge that there may be truth in the underlying metaphors behind these beliefs, which either might be classified as knowledge or lead to misconceptions.

In the face of the apparent incommensurability of knowledge systems, Eco-School support workers are essentially forced to make rules about what does and does not count as indigenous knowledge in the Eco-School. There did not seem to be a great deal of self-reflection, however, on the ethics of the rules of the discourse, with only one interviewee indicating that she wondered what right she had to 'deconstruct' traditional myths and beliefs. This is an area that Eco-School support workers could reflect on further. 
The rules surrounding the deployment of indigenous knowledges in the Eco-School also pose significant ethical questions for WESSA about the ways in which knowledge systems are positioned if they result in a hierarchy of these systems, and the ways in which various knowledge systems are validated. Within the South African Eco-School, certain types of knowledge are taught and particular knowledges are sanctioned, while other knowledges are dismissed or downgraded to superstitious beliefs.

Interestingly, many teachers in South Africa do not hold these 'superstitious beliefs'. As Masuku van Damme and Neluvhalani (2004:356) argue, South African teachers have paradoxically become 'active participants in the subjugation of [their] own local ways of knowing' through their participation in post-apartheid processes of educational reform. Thus, many teachers have already internalised and proactively endorse the illegitimacy of their own knowledges and cultures. So, many Eco-School support workers, who are on the one hand seeking to dismantle and deconstruct traditional 'beliefs', are on the other hand attempting to mobilise the take-up of indigenous knowledges through their Eco-School work. What seems to separate indigenous 'beliefs' from indigenous knowledges for Eco-School workers is whether or not the knowledge follows three key rules:

1. Indigenous knowledges are environmentally friendly and sustainable.

2. Indigenous knowledges are validated through scientific knowledge.

3. Indigenous knowledges are static and rooted deep in history.

\section{Rule 1: Indigenous knowledges are environmentally friendly and sustainable}

WESSA actively encourages and supports the integration of indigenous knowledges across all areas of the curriculum, but specifically targets this through its Community and Heritage theme. An examination of the WESSA Eco-Schools handbook (WESSA, 2016) shows that WESSA actively encourages and supports the integration of indigenous knowledges across all areas of the curriculum (see Table 2 for sample activities).

Many of the activities listed above refer to traditional materials and practices that are environmentally friendly or sustainable. For example, reference is made to natural materials found in the environment for building, and making clay and plant fibre objects and natural musical instruments. Traditional practices that promote positive environmental beliefs and blueprints for sustainable societies such as those found in the ethic of ubuntu are also featured in the handbook. Such inclusion presents this knowledge as appropriate and valid. Indigenous knowledges that are not environmentally friendly or that lead to environmentally destructive practices are either omitted from the handbook, or if included, are critiqued as superstitious 'beliefs' and not given the status of 'acceptable' indigenous knowledge.

Limiting what counts as indigenous knowledge in this way runs the risk of constructing and representing indigenous peoples as those living close to the land, attuned to or part of nature, and living in balance with their environment (Berkes, 1999). This romanticisation of indigenous peoples and their knowledges creates an uncritical, essentialised and homogenised view of indigenous peoples as either noble savages (Neumann, 2000), or ecological warriors (Davis, 2006) who are uniquely endowed with some esoteric secret knowledge required to save the 
planet. Such a view 'fixes' indigenous people to an imagined green utopia of pre-modernity, granting these people value only when they are living traditional lives. While at first glance efforts to incorporate indigenous knowledge may appear to be positive, the risk is that such efforts may do nothing more than reproduce the notion of a primitive, exotic Other. What this does is reify the noble savage of the past while representing indigenous peoples of the present as fallen angels who have been contaminated by development and modernity and who are now often seen as a threat to the environment (Berkes, 1999; Neumann, 2000). It is therefore important for environmental educators to challenge any homogeneity of indigenous knowledges evident in the field and instead seek to ensure that such knowledges are not fixed or relegated to a romanticised green utopian past (O’Hern \& Nozaki, 2014; Shava, 2008).

Table 2. Selected activity suggestions from the Eco-Schools handbook

\begin{tabular}{|c|c|c|}
\hline Subject & $\begin{array}{l}\text { Eco-School } \\
\text { theme }\end{array}$ & Activity suggestion \\
\hline \multicolumn{3}{|r|}{ Year 4} \\
\hline $\begin{array}{l}\text { Natural } \\
\text { Sciences/ } \\
\text { Technology }\end{array}$ & $\begin{array}{l}\text { Community } \\
\text { and Heritage }\end{array}$ & $\begin{array}{l}\text { - Structures for animal shelters. Issues of animal welfare and needs } \\
\text { of animals in terms of shelter can be explored. This can sometimes } \\
\text { be linked to mistreatment of animals within the community as an } \\
\text { issue. } \\
\text { - Exploration of indigenous structures and traditional homes - use of } \\
\text { natural materials found in the environment. } \\
\text { - Cultures and moral lessons - look at different cultures in South } \\
\text { Africa, what foods do they eat? What beliefs do they have regarding } \\
\text { the environment? What traditional knowledge do they have that is } \\
\text { a good environmental practice? }\end{array}$ \\
\hline \multicolumn{3}{|r|}{ Year 5} \\
\hline $\begin{array}{l}\text { Natural } \\
\text { Sciences/ } \\
\text { Technology }\end{array}$ & $\begin{array}{l}\text { Community } \\
\text { and Heritage }\end{array}$ & $\begin{array}{l}\text { - Traditional processing and African use of natural materials. Making } \\
\text { an object from clay and finding examples of objects made from } \\
\text { plant fibre. }\end{array}$ \\
\hline \multicolumn{3}{|r|}{ Year 7} \\
\hline $\begin{array}{l}\text { Creative } \\
\text { Arts }\end{array}$ & $\begin{array}{l}\text { Community } \\
\text { and Heritage }\end{array}$ & $\begin{array}{l}\text { - Response to different stimuli - stimulus could be a theme } \\
\text { (corresponding with school's action project, i.e. extending our } \\
\text { hand to those around us/traditional living), idea (e.g. ubuntu), story, } \\
\text { pictures (of an environmental issue), music (traditional music/music } \\
\text { from different cultures). }\end{array}$ \\
\hline
\end{tabular}

\section{Rule 2: Indigenous knowledges are validated through scientific knowledge}

Through its Share-Net Programme, WESSA also distributes environmental education resources to support South African Eco-Schools in integrating indigenous knowledge perspectives (Masuku Van Damme \& Neluvhalani, 2004). These resources grew out of several research projects conducted over the past two decades that began the painstaking task of recovering what had been marginalised and forgotten over decades of colonial domination 
and apartheid. Projects on topics such as Nguni grain storage (Mtshali cited in Masuku, 1999), traditional 'sweet water' collection practices (Manqele, O’Donoghue, Masuku, Le Roux \& Ndlovu, 1998), traditional uses of Ziziphus mucronata (buffalo thorn tree) and beer production (Hanisi in O'Donoghue, Lotz-Sisikta, Asafo-Adjei, Kota \& Hanisi, 2009) have provided the basis for the principal and authoritative indigenous knowledge resources used by South African Eco-Schools.

An example of these resources is Umqombothi: Beer, ants and ancestors (WESSA Share-Net, n.d.), which provides a case study of how indigenous knowledges contributed to addressing problems of earlier times. The resource provides an overview of the traditional practice of making sorghum beer, and the value and uses of the beer and its by-products. A sample extract from this resource shows how indigenous knowledge is presented (italics in original):

Nothing was wasted from the beer making process. The froth at the top was skimmed and kept in the hut for baking purposes as it has a high yeast content. Women frequently made dumplings (ujeqe) with the yeast from beer making. The froth was a result of alcoholic fermentation which takes place because the sprouted sorghum that was added in the last stages of brewing contains sugars, glucose, and fructose. These decompose into alcohol and carbon dioxide. The enzymes responsible for decomposition are zymase, maltase and invertase. The active ferment in this case is yeast or saccharomyces, and the process is called alcoholic fermentation. Because the surface froth in sorghum beer has a high content of yeast, it was traditionally used for brewing and baking. (WESSA Share-Net, n.d.:2)

In this extract, the indigenous knowledge and practice is first presented, outlining how the froth at the top of the beer was kept for baking purposes and for making ujege (dumplings). Secondly, in italics underneath, a scientific explanation for this phenomena is provided, describing why froth makes such a good raising agent for further baking activities. This same format is repeated several times throughout the resource. Although these materials were written with the aim of opening opportunities for inter-epistemological dialogue, encouraging teachers to interplay scientific and cultural knowledges (Masuku van Damme \& Neluvhalani, 2004), one could also argue that presenting knowledge in this way encourages a practice whereby indigenous knowledges are only validated when supported by scientific explanations.

Validating indigenous knowledges through scientific explanations is common in WESSA Eco-School practice. This is illustrated in the following discussion with Eco-School support workers:

ESW3: I think it's a great opportunity to look at cultural practices or knowledge that has been passed down and to look at it critically, and very often you'll find indigenous knowledge that is beneficial to the environment and it might be coincidental but often there's a reason which when it first came about, they wouldn't have had the scientific reasons for it. Like that first sweep, when you want to drink water from a natural water resource, if you look at the number of contaminants or pathogens or bacteria in that top layer that 
is normally what would make you sick. So that would be something to be encouraged and people that practice indigenous knowledge feel really affirmed get really excited when their practices are approved of, or ...

ESW4: ...given a scientific explanation

ESW3: You know in a kind of like a 'told you so' way, but then there are some other practices, which I think this is where environmental education needs to be at the forefront of is to look at them critically and have a voice to say 'It doesn't have a place anymore, it's not good for people or the planet'.

(Eco-School Support Workers 3 and 4, 2012)

Both these extracts reflect a tendency to define or explain indigenous knowledge in relation to science (Masuku van Damme \& Neluvhalani, 2004; Semali \& Kincheloe, 1995), demonstrating that western science is the dominant standard by which other knowledges are judged. This sets up a hierarchy of knowledge systems. If environmental educators are genuinely concerned about enabling epistemological pluralism, we need to ensure that we do not privilege any one knowledge system, be it indigenous, local, religious or scientific (Odora Hoppers, 2002). To not do so means we run the risk of subsuming diverse knowledges into the 'language and logic of western knowledge systems' (Shiva, 2000:viii).

\section{Rule 3: Indigenous knowledges are static and rooted deep in history}

Another rule that emerged from interviews with Eco-Schools support workers concerned how long-standing the indigenous knowledge was. This is clearly illustrated in the following conversation between two Eco-School workers (emphasis mine):

ESW3: There's also recently, and it's been called indigenous knowledge but it's not really. People have been poisoning vultures up in Zululand. So what they do is they either kill an animal, or leave a carcass, and they put a certain kind of poison in it ... And everything comes down to eat that carcass including vultures hyenas, the whole lot ... they just all die. And they take the vulture's necks and they make that into 'muthi' ... and they make a necklace out of it hang it around your neck and people have been told this will give you the power to see the lotto numbers.

ESW4: And these are not old people, these are young people!

ESW3: Yes! So it's capitalising on a current trend, wanting to win the lottery.

ESW4: It's based on the fact that vultures circle very high so they can see everything, including the future. 
ESW3: Nowadays the 'muthi' industry has grown so big that they have collectors going out to collect stuff.

ESW4: ... who are not trained

ESW3: Yes, and a lot of 'inyangas' haven't been properly initiated or taught or anything.

ESW4: They're just anyone ...

ESW3: They've just learnt a little bit and taken it up. So when we've discussed it in class with lots of Black children, we've discussed how we've actually moved away from our traditions in a sense.

ESW4: But it's a broken down telephone as well, because a lot of indigenous knowledge is passed down orally and because the family structure isn't ...

ESW3: $\ldots$ in place ...

ESW4: ... in place, it can morph into things suitable to the current situation, like the lottery.

(Eco-School Support Workers 3 and 4, 2012)

Although this conversation reflects aspects of Rule 1 (indigenous knowledges are environmentally friendly), it also reveals a dismissal of vulture muthi as indigenous knowledge: 'it's been called an indigenous knowledge thing but it's not really'. The speakers make several references linking this 'belief' to current or contemporary events such as 'seeing lotto numbers', 'capitalising on a current trend', and 'suitable to the current situation', and use this as an argument for discounting the authenticity of such knowledges. Furthermore, they create a binary between 'current' muthi collecting practices and 'traditional' practices by claiming that the muthi collectors and inyangas (medicine men/women) involved are not properly trained or initiated. They argue that such practices are the result of family structures breaking down and a moving away from tradition. These developments have resulted in problems with the passing down of indigenous knowledge between generations. Thus, for these Eco-School support workers, authentic indigenous knowledges are rooted in historical tradition, they come from the past, and are timeless and unchanging. New 'knowledges' that arise as a result of interactions with new socio-economic factors and contexts are viewed, not only as inauthentic and untrue, but also as deceitful, dangerous and unsustainable. To be clear, we are not defending the veracity of claims about vulture muthi or arguing that these should be accorded knowledge status, but merely pointing to the way these unspoken rules define what is counted as legitimate indigenous knowledge in the Eco-School. 
The adherence to this rule by Eco-School workers results in valid indigenous knowledge being understood as only that which is a 'static repository of pre-colonial knowledge'. This fixes the speakers and holders of such knowledges to the past, thereby rendering them almost irrelevant to solving the challenges of contemporary life. Were such knowledges not relegated to the past in these ways, then they could become part of a dynamic, changing, learning process that would enable us to engage in new ways with new social and environmental conditions (Goodall, 2008; Shava, 2008).

\section{Conclusion}

The effects of the colonial subjugation of indigenous knowledges are still experienced by South African teachers, many of whom have internalised the illegitimacy of their own knowledge systems. Thus, efforts to re-appropriate and value indigenous knowledge systems may not only open up much needed sources of epistemological diversity (considering the complex wicked problems facing the planet) but also offer counter-hegemonic ways of recovering pride and national identity. However, efforts to build an epistemologically pluralistic curriculum where indigenous, cultural and scientific knowledges can coexist is not without problems. In their efforts to build such a curriculum, Eco-School support workers working at the discursive interface of different knowledges systems appear to have generated a set of discursive rules that identify what constitutes legitimate knowledge in the Eco-School. These rules, while privileging scientific knowledge, do enable the inclusion of certain indigenous knowledges. In particular, indigenous knowledges that are environmentally benign, validated by science, and rooted in historical traditions are considered legitimate forms of knowledge to deploy in and through the Eco-School.

While hesitant to confront contradictory discourses, Eco-School support workers employed a number of strategies to assist their negotiations of this discursive friction. These strategies included looking for deeper meanings behind traditional stories, recognising and appreciating the empirical basis of traditional stories, asking critical consequential questions, and adopting the language of other powerful discourses. These strategies together ensure that Eco-School support workers are able to influence and shape the thoughts and practices of Eco-School teachers about what constitutes valid knowledge.

However, indigenous knowledge discourses are still emerging as shifting, complex social constructs, particularly as they relate to other discourses within a diverse epistemological framework. It is clear that more thought needs to be given to the role and place of indigenous knowledge in Eco-schooling, particularly in its relationship to dominant western scientific ways of knowing. The difficulty of working with indigenous knowledge in ways that do not reflect simplistic binaries between western scientific and indigenous knowledges, which privilege certain forms of knowing over others, is significant within South Africa's Eco-schooling context. Such practices may have unintended consequences affecting the ways that indigenous peoples are represented and valued. 


\section{Notes on the contributors and their contributions}

\section{Lead author}

Ryan, Elizabeth (Lisa) | Southern Cross University |

ORCID 0000-0003-0688-0945 | Lisa.ryan2@sunshinecoast.qld.gov.au

Dr Lisa Ryan is Environmental Education Programming Officer at Sunshine Coast Council and Adjunct Associate Lecturer at the University of the Sunshine Coast. Her most recent research is in postcolonial theories of identity and agency in the Eco-school. Dr Ryan was affiliated to the Southern Cross University at the time of producing this research paper.

\section{Co-author}

Ferreira, Jo-Anne | Southern Cross University |

ORCID 0000-0002-3448-1477 | Jo-anne.ferreira@scu.edu.au

Prof Jo-Anne Ferreira is Director, Centre for Teaching \& Learning and Academic Director, SCU Online at Southern Cross University. Her research is in post-structuralist theories of identity, embodiment and power in environmental and sustainability education

\section{Percentage contribution}

\begin{tabular}{|l|l|l|}
\hline Areas of contribution & Authors & $\begin{array}{l}\text { Percentage } \\
\text { contribution }\end{array}$ \\
\hline $\begin{array}{l}\text { Conception or design of the paper, theory } \\
\text { or key argument }\end{array}$ & Lisa Ryan & $60 \%$ \\
\cline { 2 - 3 } & Jo-Anne Ferreira & $40 \%$ \\
\hline \multirow{2}{*}{ Data collection } & Lisa Ryan & $100 \%$ \\
\cline { 2 - 3 } & Jo-Anne Ferreira & $0 \%$ \\
\hline \multirow{2}{*}{ Analysis and interpretation } & Lisa Ryan & $70 \%$ \\
\hline \multirow{2}{*}{ Drafting the paper } & Jo-Anne Ferreira & $30 \%$ \\
\hline \multirow{2}{*}{ Critical review of paper } & Lisa Ryan & $80 \%$ \\
\cline { 2 - 3 } & Jo-Anne Ferreira & $20 \%$ \\
\hline & Lisa Ryan & $50 \%$ \\
\cline { 2 - 3 } & Jo-Anne Ferreira & $50 \%$ \\
\hline
\end{tabular}

\section{Reference List}

Anzaldúa, G. (1987). Borderlands/La Frontera: The new mestiza. San Francisco: Aunt Lute Books. Berkes, F. (1999). Sacred ecology: Traditional ecological knowledge and resource management. Philadelphia, PA: Taylor and Francis.

Bhabha, H.K. (1994). The location of culture. London: Routledge. 
Colombo, D. \& Porcu, M. (2014). Environment and neoliberalism: A critical discourse analysis of three Italian cases. Journal for Communication Studies, 7(1), 63-82.

Davis, M. (2006). Bridging the gap or crossing a bridge? Indigenous knowledge and the language of law and policy. In W. Reid, F. Berkes, T.Wilbanks, \& D. Capistrano (Eds), Bridging scales and knowledge systems: Concepts and applications in ecosystem assessment (pp. 145-163). Washington DC: Island Press.

Dei, G., Hall, B. \& Rosenberg, D. (Eds). (2000). Indigenous knowledges in global contexts: Multiple readings of our world. Toronto: University of Toronto Press.

Dryzek, J.S. (2013). The politics of the earth: Environmental discourses (3rd ed.). Oxon: Oxford University Press.

Eco-Schools. (n.d.). Eco-Schools global homepage. http://www.ecoschools.global/

Eco-Schools. (2014). Seven steps towards an Eco-School. http://www.ecoschools.global/sevensteps/

Ellen, R. (2002). From ethnoscience to science, or 'what indigenous knowledge debate tells us about how scientists define their project'. Journal of Cognition and Culture, 4(3), 409-450.

Eze, M.O. (2010). Intellectual history in contemporary South Africa. New York: Palgrave Macmillan.

FEE (Foundation for Environmental Education). (2012). Rules of Procedure for Foundation for Environmental Education. http://www.fee.global/becoming-a-member/

Foucault, M. (1980). Power/knowledge: Selected interviews and other writings (C. Gordon, Ed.). New York: Pantheon.

Giddens, A. (1991). Modernity and self-identity. Cambridge: Polity Press.

Goodall, H. (2008). Riding the tide: Indigenous knowledge, history and water in a changing Australia. Environment and History, 14(3), 355-384.

Howes, M., McKenzie, M., Gleeson, B., Gray, R., Byrne, J. \& Daniels, P. (2010). Adapting ecological modernisation to the Australian context. Journal of Integrative Environmental Sciences, 7(1), 5-21. DOI 10.1080/19438150903478597

Huckle, J. (2009). Sustainable schools: Responding to new challenges and opportunities. Geography, 94(1), 13-21.

Kanu, Y. (2011). Reappropriating traditions in the postcolonial curricular imagination. In Y. Kanu (Ed.), Integrating aboriginal perspectives into the school curriculum: Purposes, possibilities, and challenges (pp. 203-222). Toronto: University of Toronto Press.

Kumalo, S.H. (2017). Problematising development in sustainability: Epistemic justice through an African ethic. Southern African Journal of Environmental Education, 33(1), 14-24.

Le Grange, L. (2012). Ubuntu as an architectonic capability. Indilinga: African Journal of Indigenous Knowledge Systems, 11(2), 139-145.

Lotz-Sisikta, H. (2002). Curriculum patterning in environmental education: A review of developments in formal education in South Africa. In E.J. van Rensburg, J. Hattingh, H. Lotz-Sisikta \& R. O’Donoghue (Eds), Environmental education, ethics and action in southern africa (pp. 97-120). Pretoria: Human Sciences Research Council Press.

Lotz-Sisikta, H. (2006). Enabling environmental and sustainability education in South Africa's national curriculum: Context, culture and learner aspirations for agency. In C. Lee \& 
M. Williams (Eds), Environmental education and geographical education for sustainability: Cultural contexts (pp. 321-334). New York: Nova Science Publishers.

Manqele, M., O’Donoghue, R., Masuku, L., Le Roux, K. \& Ndlovu, N. (1998). Sweet water. Natal Parks Board and WESSA (Ed.). Howick: Share-Net.

Masuku, L.S. (1999). The role of indigenous knowledge in/for environmental education: The case of a Nguni story in the schools water action project. Master's thesis, Department of Education, Rhodes University, Grahamstown.

Masuku van Damme, L. \& Neluvhalani, E. (2004). Indigenous knowledge in environmental education processes: Perspectives on a growing research arena. Environmental Education Research, 10(3), 353-370.

Mol, A.P.J. \& Sonnenfeld, D. A. (Eds). (2000). Ecological modernisation around the world: Perspectives and critical debates. London and Portland, OR: Frank Cass/Routledge.

Neumann, R.P. (2000). Primitive ideas: Protected area buffer zones and the politics of land in Africa. In V. Broch-Due \& R.A. Schroeder (Eds), Producing Nature and Poverty in Africa (pp. 220-240). Stockholm: Nordisk Afrikainstitutet.

Nygren, A. (1999). Local knowledge in the environment-development discourse. Critique of Anthropology, 19(3), 267-288. DOI 10.1177/0308275x9901900304

O’Donoghue, R., Lotz-Sisikta, H., Asafo-Adjei, R., Kota, L. \& Hanisi, N. (2009). Exploring learning interactions arising in school-in-community contexts of socio-ecological risk. In A.E.J. Wals (Ed.), Social learning towards a sustainable world: Principles, perspectives, and praxis (pp. 435-448). The Netherlands: Wageningen Academic Publishers.

O'Hern, D. \& Nozaki, Y. (2014). Natural science education, indigenous knowledge, and sustainable development in rural and urban schools in Kenya: Toward critical postcolonial curriculum policies and practices (Vol. 6). Rotterdam: Sense Publishers.

Odora Hoppers, C.A. (2002). Indigenous knowledge and the integration of knowledge systems: Towards a conceptual and methodological framework. In C.A. Odora Hoppers (Ed.), Indigenous knowledge and the integration of knowledge systems. Claremont, South Africa: New Africa Books.

Ramose, M.B. (2014). Dying a hundred deaths: Socrates on truth and justice. Phronimon, 15(1), 67-80.

Redclift, M. (1994). Development and the environment: Managing the contradictions? In L. Sklair (Ed.), Capitalism and Development (pp. 123-139). London: Routledge.

Rittel, H.W., \& Webber, M. M. (1973). Dilemmas in a general theory of planning. Policy sciences, $4(2), 155-169$.

Ryan, E. (2017). Localising the global Eco-Schools program in South Africa: A postcolonial analysis. $\mathrm{PhD}$ thesis, Southern Cross University, Lismore, Australia.

Semali, L. \& Kincheloe, J. (Eds). (1995). What is indigenous knowledge? Voices from the Academy. New York: Falmer/Taylor \& Francis.

Shava, S. (2008). Indigenous knowledges: A genealogy of representations and applications in developing contexts of environmental education and development in Southern Africa. PhD thesis, Rhodes University, Grahamstown, South Africa. 
Shava, S. (2013). The representation of indigenous knowledge. In M. Brody, R.B. Stevenson, A. Wals \& J. Dillon (Eds), International Handbook of Research on Environmental Education (pp. 384-393). New York and Oxon: Routledge.

Shiva, V. (2000). Foreword: Cultural diversity and the politics of knowledge. In B. Hall, G. Dei, \& D. Rosenberg (Eds), Indigenous knowledges in global contexts: Multiple readings of our world. Toronto: University of Toronto Press.

United Nations. (2007). United Nations Declaration on the Rights of Indigenous Peoples. New York: UN General Assembly.

UNEP-FEE. (2003, 3rd March). Memorandum of Understanding establishing the global partnership between Foundation for Environmental Education and United Nations Environment Programme. http://www.Eco-schools.it/public/documenti/docum/fee-unep. pdf

Valentine, G. (1997). Tell me about ... : Using interviews as a research methodology. In R. Flowerdew \& D.M. Martin (Eds), Methods in human geography: A guide for students doing a research project (pp. 110-127). Abingdon, Oxon: Routledge.

Weedon, C. (1987). Feminist practice and poststructural theory. Oxford: Basil Blackwell.

WESSA (Wildlife and Environment Society of South Africa). (2016). Eco-Schools South

Africa Handbook. Howick, KZN: WESSA. http://www.wessa.org.za/uploads/documents/ Eco-schools/WESSA_Eco-schools_Handbook_CAPS_aligned_-_updated_June_2016.pdf

WESSA Share-Net (n.d.). Umquombothi: Beer, ants and ancestors. Indigenous Knowledge Resource Series. Howick: Share-Net. 
